\title{
Tungsten-182 and Neodymium-142 evidence for an ancient kimberlite source
}

NAO NAKANISHI ${ }^{1}$, RICHARD W. CARLSON ${ }^{2}$, MARY F. HORAN $^{2}$, ANDREA GIULIANI $^{3,4}$, JON WOODHEAD $^{4}$, D. GRAHAM PEARSON $^{5}$ AND RICHARD J. WALKER ${ }^{1}$

${ }^{1}$ University of Maryland

${ }^{2}$ Carnegie Institution for Science

${ }^{3}$ ETH Zurich

${ }^{4}$ University of Melbourne

${ }^{5}$ University of Alberta

Presenting Author: nnakanis@umd.edu

Kimberlites are igneous rocks that are derived from the deep mantle. Recent studies of compiled ${ }^{143} \mathrm{Nd} /{ }^{144} \mathrm{Nd},{ }^{176} \mathrm{Hf} /{ }^{177} \mathrm{Hf}$, and ${ }^{87} \mathrm{Sr} /{ }^{86} \mathrm{Sr}$ data for a global suite of kimberlites suggest that at least some kimberlites originate from a primitive, isotopicallyhomogenous, deep mantle reservoir that evolved in isolation for at least 2.5 billion years $[1,2]$. To decipher whether or not this reservoir preserves remnants of an early-formed mantle domain, we report ${ }^{182} \mathrm{~W} /{ }^{184} \mathrm{~W}$ and ${ }^{142} \mathrm{Nd} /{ }^{144} \mathrm{Nd}$ data for kimberlites from ten worldwide localities, ranging in age from 1153 to $52 \mathrm{Ma}$. Most are characterized by uniform $\mu^{182} \mathrm{~W}$ and $\mu^{142} \mathrm{Nd}$ values (ppm difference in ${ }^{182} \mathrm{~W} /{ }^{184} \mathrm{~W}$ and ${ }^{142} \mathrm{Nd} /{ }^{144} \mathrm{Nd}$ between sample and standards) averaging $-5.9 \pm 1.0 \mathrm{ppm}(2 \mathrm{SE}, \mathrm{n}=13)$ and +2.7 $\pm 1.2 \mathrm{ppm}(2 \mathrm{SE}, \mathrm{n}=6)$, respectively. The remarkably homogeneous, modestly negative $\mu^{182} \mathrm{~W}$ values, coupled with chondritic to supra-chondritic initial ${ }^{143} \mathrm{Nd} /{ }^{144} \mathrm{Nd}$ and ${ }^{176} \mathrm{Hf} /{ }^{177} \mathrm{Hf}$ ratios over a span of nearly $1000 \mathrm{Myr}$ is powerful evidence that the kimberlites were derived from an early-formed mantle reservoir that was largely isolated from the convective vigor of the accessible upper mantle throughout Earth history. Possible explanations for the modestly negative $\mu^{182} \mathrm{~W}$ value include the ancient transfer of $\mathrm{W}$ from the core to the mantle source reservoir, creation of the source reservoir as a result of early silicate fractionation, or an overabundance of late accreted materials in the source reservoir. Each of these possibilities requires a well-mixed, deep mantle source to leave a globallyaccessible, isotopically-uniform reservoir.

By contrast, two younger kimberlites emplaced at 72 and 52 $\mathrm{Ma}$, and characterized by lower initial ${ }^{176} \mathrm{Hf} /{ }^{177} \mathrm{Hf}$ and ${ }^{143} \mathrm{Nd} /{ }^{144} \mathrm{Nd}$ than the older kimberlites, have $\mu^{182} \mathrm{~W}$ values consistent with the modern upper mantle. This is consistent with the interpretation that the mantle source of some kimberlites younger than $200 \mathrm{Ma}$ was modified by the incorporation of a deeply subducted component with low ${ }^{143} \mathrm{Nd} /{ }^{144} \mathrm{Nd}$ and ${ }^{176} \mathrm{Hf} /{ }^{177} \mathrm{Hf}$. The ${ }^{182} \mathrm{~W}$ isotopic compositions likely reflect contamination of the ancient kimberlite source with the addition of recycled crustal components with $\mu^{182} \mathrm{~W} \geq 0$.

[1] Woodhead et al., 2019. Nature, 573, 578-581

[2] Giuliani et al., 2021. PNAS, 118, e2105211118 